\title{
Efek Kandungan Minyak Jarak pada Bahan Bakar Solar terhadap Konsumsi Bahan Bakar dan Emisi Jelaga Mesin Diesel
}

\author{
Syarifudin $^{1}$, Firman Lukman Sanjaya ${ }^{2}$ \\ 1,2Program Studi Teknik Teknik Mesin, Politeknik Harapan Bersama, Indonesia \\ Email: ${ }^{1}$ syarifudin.poltektegal2018@ gmail.com, ${ }^{2}$ sanjaya.firman51@ gmail.com
}

\begin{abstract}
ABSTRAK
Minyak jarak merupakan bahan bakar alternatif sebagai pengganti bahan bakar solar. Propertis yang mendekati bahan bakar solar membuat minyak jarak membantu dalam mengurangi ketergantungan bahan bakar fosil. Bahan baku yang berlimpah dan propertis angka setana yang tinggi membuat minyak jarak banyak digunakan sebagai bahan bakar pada mesin diesel. Penelitian ini bertujuan mengobservasi konsumsi bahan bakar dan emisi jelaga yang dihasilkan mesin diesel menggunakan bahan bakar campuran solar dengan kandungan minyak jarak sebesar 30\%. Berdasarkan hasil eksperimen yang sudah dilakukan, konsumsi bahan bakar dan emisi jelaga terjadi peningkatan. Peningkatan tertingi terjadi pada bahan bakar SJ30 saat pembebanan 25\%. Nilai kalor yang rendah menjadi penyebab utama peningkatan konsumsi dan emisi jelaga.
\end{abstract}

Kata kunci: Minyak jarak, konsumsi bahan bakar, emisi jelaga, mesin diesel

\begin{abstract}
Castor oil is an alternative fuel as a substitute for diesel fuel. The property that approaches diesel fuel makes jatropha oil help reduce fossil fuel dependence. Abundant raw materials and high cetane properties make castor oil widely used as fuel in diesel engines. This study aims to observe the consumption of fuel and soot emissions produced by diesel engines using a mixture of diesel fuel with castor oil content of $30 \%$. Based on the results of experiments that have been carried out, fuel consumption and soot emissions have increased. The highest increase occurred in SJ30 fuel at $25 \%$ loading. Low heating value is a major cause of increased consumption and soot emissions.
\end{abstract}

Keywords: Castor oil, Fuel consumption, Soot emission, Diesel engine.

\section{Pendahuluan}

Pertumbuhan kendaraan bermotor setiap tahunnya terus meningkat. Menurut Badan Pusat Statistika Indonesia (BPS), pada tahun 2018 terjadi peningkatan kendaraan bermotor sebesar 7,03\% dibandingkan tahun 2017. Peningkatan tertinggi terjadi pada kendaraan jenis penumpang dan angkutan (berpenggerak mesin diesel) sebesar 6,08\%. Data ini menunjukkan bahwa ketergantungan bahan bakar solar setiap tahunnya semakin tinggi. Bahan bakar solar merupakan minyak bumi hasil eksplorasi penambangan dari fosil. Bahan bakar solar merupakan bahan bakar tidak terbarukan, sehingga tidak dapat diproduksi ketika stok minyak bumi habis. Oleh karenanya perlu bahan bakar alternatif sebagai solusi peningkatan volume kendaraan bermotor.

Minyak jarak di produksi dari biji pohon jarak. Pohon jarak merupakan tanaman tropis sehingga mudah dibudidayakan di Indonesia. Minyak jarak memiliki propertis yang hampir sama dengan bahan bakar solar [1]. Minyak jarak memiliki angka setana 41,8 [2]. Angka setana yang tinggi sebagai indikator kualitas bahan bakar bakar [3]. Selain itu, minyak jarak memiliki kandungan oksigen yang dibutuhkan dalam proses pembakaran mesin diesel [4]. Atas dasar tersebut, minyak jarak sangat cocok dijadikan sebagai bahan campuran atau pengganti bahan bakar solar [5].

Menurut Syarifudin (2018) [6], penggunaan minyak jarak dapat mengurangi ketergantungan bahan bakar. Selain itu, daya yang dihasilkan mesin diesel berbahan bakar campuran solar-minyak jarak hampir mendekati bahan bakar solar murni [7]. Hal ini didukung adanya kandungan oksigen yang tinggi dalam minyak jarak.

Oleh karena itu, penelitian ini mengobservasi dampak penambahan minyak jarak pada bahan bakar solar terhadap konsumsi dan emisi jelaga yang dihasilkan mesin diesel. 


\section{Metodologi Penelitian}

Penelitian dilakukan di Laboratorium Thermo Fluida Universitas Diponegoro tahun 2018. Pengujian menggunakan mesin diesel injeksi langsung merk Isuzu tipe 4JB1 yang spesifikasinya dijelaskan pada tabel 1 . Pada Gambar 1 merupakan skema pengujian penelitian.

Tabel 1. Spesifikasi mesin

\begin{tabular}{ll}
\hline \multicolumn{2}{c}{ Mesin Isuzu 4JB1 } \\
\hline Tipe mesin & Isuzu 4JB1 \\
Jumlah silinder & 4, Vertical In-line, Injeksi \\
& langsung \\
Diameter silinder & $93 \mathrm{~mm}$ \\
Langkah & $102 \mathrm{~mm}$ \\
Jumlah volume silinder & $2771 \mathrm{cc}$ \\
Rasio kompresi & $18,2: 1$ \\
Torsi maksimum & $178,96 \mathrm{Nm}$ \\
Daya maksimum & $52,2 \mathrm{~kW}$ \\
\hline
\end{tabular}

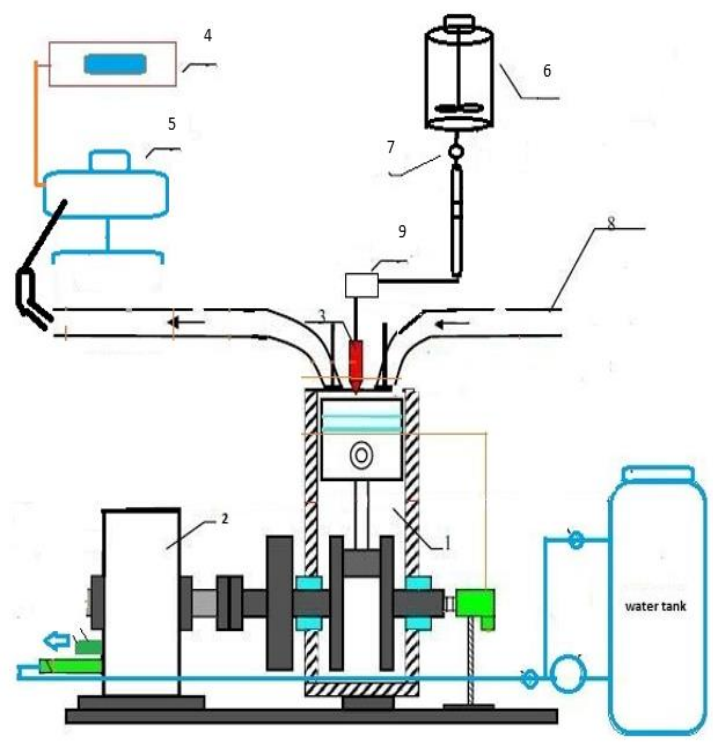

Gambar 1. Skema Pengujian

Keterangan:

1. Mesin diesel

2. Dinamometer

3. Injektor

4. Gas analyzer Stargass 898

5. Smoke meter

6. Mixer bahan bakar

7. Katup bahan bakar

8. Intake manifold

Peralatan percobaan disusun seperti pada Gambar 1. Campuran bahan bakar yang sudah disiapkan sesuai dengan persentase komposisi bahan bakar dituangkan ke dalam mixer bahan bakar agar homogen. Katup ini dibuka untuk mengalirkan bahan bakar ke mesin diesel. Mesin diesel diatur pada putaran konstant sebesar 2500 rpm. Smoke meter OTC 495 dan Gas analyzer Stargas 898 untuk mengukur emisi jelaga yang dihasilkan mesin diesel. Pencatatan dilakukan saat volume bahan bakar 100ml terlihat kosong pada mixer bahan bakar. Selanjutnya hasil pengujian diolah menggunakan software Ms. Excel 2010 dan dibuat grafik dengan bantuan Software Origin 8.

Persentase komposisi bahan bakar yang digunakan dijelaskan pada tabel 2. Adapun propertis bahan bakar yang digunakan pada Tabel 3 .

Tabel 2. Persentase komposisi bahan bakar

\begin{tabular}{cccc}
\hline \multirow{2}{*}{ No } & \multirow{2}{*}{$\begin{array}{c}\text { Komposisi bahan } \\
\text { bakar }\end{array}$} & \multicolumn{2}{c}{ Volume (ml) } \\
\cline { 3 - 4 } & & Solar & Minyak jarak \\
\hline 1 & S100 & 1000 & 0 \\
2 & SJ30 & 700 & 300 \\
\hline
\end{tabular}

Tabel 3. Propertis bahan bakar

\begin{tabular}{clcc}
\hline No & $\begin{array}{c}\text { Propertis bahan } \\
\text { bakar }\end{array}$ & Solar & Minyak Jarak \\
\hline 1 & Angka setana & 48 & 41,8 \\
2 & Kadar air (\%v) & 0,05 & 3,16 \\
& Viskositas pada & $2,0-5,0$ & 3,23 \\
3 & suhu 40 ${ }^{\circ} \mathrm{C}(\mathrm{m} . P a . s)$ & 45,21 & 37,97 \\
4 & Nilai kalor $(\mathrm{MJ} / \mathrm{kg})$ & 60 & 198 \\
5 & Titik nyala $\left({ }^{\circ} \mathrm{C}\right)$ & - & 10,9 \\
6 & Kandungan oksigen & & \\
\hline
\end{tabular}

\section{Hasil dan Pembahasan}

3.1 Konsumsi bahan bakar mesin diesel injeksi langsung menggunakan bahan bakar campuran solar-minyak jarak

Konsumsi bahan bakar adalah perbandingan banyaknya pemakaian bahan bakar setiap jam tiap daya yang dihasilkan [8].

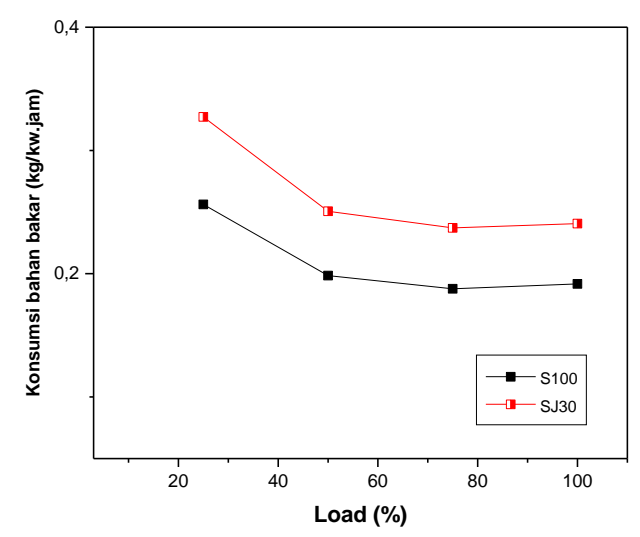

Gambar 2. Konsumsi bahan bakar mesin diesel injeksi langsung berbahan bakar campuran solar-minyak jarak

Pada Gambar 2 menampilkan konsumsi bahan bakar mesin diesel menggunakan bahan bakar 
campuran solar-minyak jarak. Penggunaan bahan bakar campuran solar-minyak jarak menghasilkan konsumsi yang lebih tinggi dibandingkan solar murni (S100). Rendahnya nilai kalor dalam minyak jarak menyebabkan penurunan temperatur pembakaran sehingga mengurangi kualitas pembakaran dan meningkatkan konsumsi bahan bakar [9].

Konsumsi bahan bakar tertinggi terjadi pada pembebanan $25 \%$ menggunakan bahan bakar campuran solar-minyak jarak sebesar $0,327 \mathrm{~kg} / \mathrm{kW}$.jam

\subsection{Emisi Jelaga mesin diesel injeksi langsung menggunakan bahan bakar campuran solar- minyak jarak}

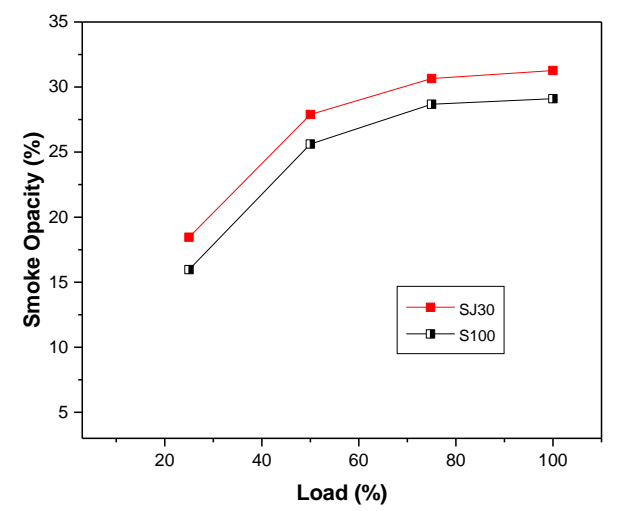

Gambar 3. Emisi jelaga mesin diesel injeksi langsung berbahan bakar campuran solar-minyak jarak

Gambar 3 mempresentasikan emisi jelaga yang dihasilkan mesin diesel. Secara umum, emisi jelaga terjadi peningkatan seiring kenaikan beban. Hal ini akibat peningkatan penginjeksian bahan bakar untuk menstabilkan putaran mesin [10]. Penggunaan minyak jarak sebagai bahan campuran pada bahan bakar solar menghasilkan emisi jelaga yang lebih tinggi dibandingkan solar murni (SJ100). Hal ini akibat nilai kalor yang rendah pada minyak jarak menurunkan temperatur pembakaran dan memicu peningkatan emisi jelaga akibat adanya bahan bakar yang tidak terbakar [11].

Peningkatan emisi jelaga tertinggi terjadi pada bahan bakar campuran solar-minyak jarak sebesar $13,46 \%$ saat pembebanan $25 \%$ dibandingkan S100.

\section{Kesimpulan}

Kesimpulan pada penelitian ini adalah penambahan minyak jarak pada bahan bakar solar mengakibatkan peningkatan konsumsi bahan bakar dan emisi jelaga mesin diesel. Rendahnya nilai kalor pada minyak jarak merupakan penyebab utama peningkatan konsumsi dan emisi jelaga mesin diesel.

\section{Daftar Pustaka}

[1] Darmana E., Syaiful, Fajar B. 2013. "Pengaruh cold egr terhadap daya pada mesin diesel dengan bahan bakar campuran solar dan jatropa," Eksergi Jurnal Teknik Energi. vol. 9, no.3.

[2] Syarifudin dan Syaiful, 2019. "Pengaruh penggunaan energi terbarukan butanol terhadap penurunan emisi jelaga mesin diesel injeksi langsung berbahan bakar biodiesel campuran solar dan jatropa," Infotekmesin, vol. 10, no. 1.

[3] Can O, 2014. "Combustion characteristics, performance and exhaust emissions of a diesel engine fueled with a waste cooking oil biodiesel mixture," Energy Conversion Management, 87 pp. 676-686..

[4] Syarifudin dan Syaiful, 2019. "Daya dan emisi jelaga dari mesin diesel berbahan bakar solarjatropa-butanol," Jurnal Rekayasa Mesin, vol. 14, no. 3.

[5] Pandey V.C, Singh K, Singh J.S, Kumar A, Singh B, dan Singh R.P, 2012. "Jatropha curcas: A potential biofuel plant for sustainable environmental development," Renewable and Sustainable Energy Reviews, 16. pp.2870-2883.

[6] Syarifudin, Syaiful, dan Yohana E, 2018. "Effect of butanol on fuel consumption and smoke emission of direct injection diesel engine fueled by jatropha oil and diesel fuel blends with cold EGR system," SHS Web Conference., vol. 49.

[7] Ileri E, Atmanli A, dan Yilmaz N, 2016. "Comparative analyses of n-butanol-rapeseed oil-diesel blend with biodiesel, diesel and biodiesel-diesel fuels in a turbocharged direct injection diesel engine," Journal Energy Institute. vol. 89, pp. 586-593.

[8] Cappenberg A. D, 2017. "Pengaruh penggunaan bahan bakar solar, biosolar dan pertamina dex terhadap prestasi motor diesel silinder tunggal," Jurnal. Konversi Energi dan Manufaktur UNJ, vol. 2, hal. 70-74.

[9] Senthilkumar R, Ramadoss K, dan R. Manimarans R, 2013. "Experimental Investigation of performance and emission characteristics by different exhaust gas recirculation methods used in diesel engine," Global Journal of Researches in Engineering Mechanical and Mechanics Enginering," vol. 13, no. 1.

[10] Mani M, NagarajanG, dan Sampath S, 2010, "An experimental investigation on a di diesel engine using waste plastic oil with exhaust gas recirculation," Fuel, 89, pp. 1826-1832. 
DOI: 10.35970/accurate.v1i1.173

[11] Ibrahim A, 2016. "Performance and combustion butanol-biodiesel-diesel blends," Applied characteristics of a diesel engine fuelled by Thermal. Engineering, 103, pp. 651-659. 